$\underline{\text { Article }}$

\title{
FTIR Thermal Analysis on Organofunctionalized Silica Gel
}

\author{
José L. Foschiera, Tania M. Pizzolato and Edilson V. Benvenutti* \\ Instituto de Química, Universidade Federal do Rio Grande do Sul, C. P. 15003, 91501-970, Porto Alegre - RS, Brazil
}

\begin{abstract}
Sílica gel modificada com grupos orgânicos tem sido muito utilizada como fase estacionária para cromatografia líquida. Reações de enxerto podem ser usadas na obtenção de superfícies modificadas estáveis de sílica gel. Neste trabalho a sílica gel $\left(10 \mathrm{~nm}\right.$ de diâmetro de poro e $320 \mathrm{~m}^{2}$ $\mathrm{g}^{-1}$ de área superficial) foi modificada quimicamente com 3-cloropropiltrimetoxisilano ou com 3-aminopropiltrimetoxisilano e posteriormente com anilina, $p$-anisidina, benzilamina e 3-fenilpropilcloreto a fim de se obter grupos aromáticos imobilizados na superfície de sílica gel. A espectroscopia no infravermelho foi utilizada para a caracterização dos grupos aromáticos enxertados, usando-se uma cela de quartzo. Os sólidos foram aquecidos a várias temperaturas em alto vácuo sendo que as áreas sob as bandas dos grupos orgânicos obtidas no infravermelho foram usadas para estimar a estabilidade térmica.
\end{abstract}

Silica gel modified with organic groups is widely used as a stationary phase for liquid chromatography. Grafting synthesis can be used to obtain stable modified silica gel surfaces. In this work, silica gel (10 nm of pore diameter and surface area of $\left.320 \mathrm{~m}^{2} \mathrm{~g}^{-1}\right)$ was chemically modified with 3-chloropropyltrimethoxysilane or 3-aminopropyltrimethoxysilane and reacted with aniline, $p$-anisidine, benzylamine and 3-phenylpropylchloride in order to yield aromatic groups immobilized on the silica gel surface. Infrared spectroscopy was utilized for characterization of the aromatic groups grafted on the silica gel surface, using a quartz cell. The solids were heated at several temperatures in high vacuum and the infrared band areas of the organic groups were used to evaluate the thermal stability.

Keywords: organofunctionalized silica gel, solid phase, thermal analysis, infrared analysis.

\section{Introduction}

Silica gel modified with organic groups has been extensively studied in the last two decades ${ }^{1-4}$ and it has been widely used as an adsorbent material ${ }^{2-4}$. Stable bonded organic groups on a silica gel surface can be obtained using a grafting synthesis. The organosilane $\mathrm{Y}_{3} \mathrm{Si}-\mathrm{R}-\mathrm{X}$ is a very common agent used in the grafting process ${ }^{2,5-8}, \mathrm{Y}$ is usually a halide or alkoxy group, $\mathrm{R}$ a linear chain and $\mathrm{X}$ an halide or amine group. Using a $\mathrm{SN}_{2}$ reaction, the immobilization of several organic groups can be achieved. When $\mathrm{X}$ is a halide group, the covalent bond between aromatic groups and the immobilized intermediate groups can be easily monitored by the positive halide test with silver nitrate, carried out during the reaction. The presence of halide in the liquid reaction medium is an evidence for the reaction between the nucleophilic amine group and the electrophilic carbon, with effective covalent bond formation. The well established grafting process can be used for several organic groups. Due

\footnotetext{
*e-mail:edilson@iq.ufrgs.br
}

to the high stability of the organic phase, a consequence of the covalent bond with the silica surface, these systems can be used as adsorbents for SPE (Solid Phase Extraction), in a pre concentration of organic compounds with environmental interest ${ }^{9,10}$.

TGA (Thermal Gravimetric Analysis) is a useful procedure for the characterization of the organic grafting process $7,11-15$. This technique allows the study of interaction strength between the attached organic groups and the surface with increasing temperature. However TGA is a limited technique since it is difficult to differentiate between organic and water mass loss, the latter produced by dehydroxylation of silanol which takes place with increasing temperature ${ }^{16,17}$. It has been reported that, in some cases, the organic thermal decomposition occurs in more than one step ${ }^{12,13}$. Thus the TGA technique could not be used for the identification of the desorbed organic groups in a specific step. In order to make a more complete analysis of the desorbed groups by thermal treatment, TGA and FT-IR techniques have been used in analyses of the spectra of the solid phase remaining after organic thermal degradation ${ }^{15,18}$ or in the identification of the species desorbed by thermal treatment ${ }^{19}$. 
In this work we propose the use of infrared spectroscopy as an alternative technique for thermal analysis, without using the TGA apparatus. This procedure allows the investigation of the attached organic molecules using the areas of their specific bands. The organic groups used in this work were aniline, $p$-anisidine, benzylamine and 3phenylpropyl that were immobilized on a silica gel surface using an organosilane as a bridging molecule. The covalent bond between the aromatic groups and the silica surface was shown by the high thermal stability of these groups.

\section{Experimental}

Synthesis of $\mathrm{SiO}_{2}\left(\mathrm{CH}_{2}\right)_{3} \mathrm{Cl}$ and $\mathrm{SiO}_{2}\left(\mathrm{CH}_{2}\right)_{3} \mathrm{NH}_{2}$ (intermediates) $)^{5,6}$

Silica gel (Merck) with $10 \mathrm{~nm}$ pore diameter, 0.02 $0.05 \mathrm{~mm}$ particle size and a surface area of $320 \mathrm{~m}^{2} \mathrm{~g}^{-1}$ was activated at $150{ }^{\circ} \mathrm{C}$ under vacuum $\left(10^{-1} \mathrm{~Pa}\right)$ for $5 \mathrm{~h}$. The 3-chloropropyltrimethoxysilane or 3-aminopropyltrimethoxysilane (Merck) (46.5 mmol) was dissolved in $300 \mathrm{ml}$ of toluene (Merck). The activated silica (50 g) was then added. The mixture was stirred for $22 \mathrm{~h}$ under argon at solvent-reflux temperature. The resulting modified silica was filtered under argon in a Schlenk apparatus, washed with toluene to eliminate unreacted 3-chloropropyltrimethoxisilane or 3-aminopropyltrimethoxysilane and dried for $5 \mathrm{~h}$ under vacuum at $150{ }^{\circ} \mathrm{C}$.

\section{Synthesis of aromatic groups grafted on the $\mathrm{SiO}_{2}$}

Aniline, $p$-anisidine or benzylamine (Merck) was dissolved in $200 \mathrm{~mL}$ of toluene (Merck) and $20 \mathrm{~g}$ of $\mathrm{SiO}_{2}\left(\mathrm{CH}_{2}\right)_{3} \mathrm{Cl}$ was added. The mixture was stirred for 100 $\mathrm{h}$ under argon at solvent-reflux temperature. After this time, the solvent was changed and the same quantity of aniline, $p$-anisidine or benzylamine was added. The reaction was carried out for another $100 \mathrm{~h}$ and the resulting modified silicas were filtered under argon in a Schlenk apparatus, washed with toluene, diethyl ether and water in order to eliminate the unreacted aniline, $p$-anisidine or benzylamine. The solids were then washed with a solution of $0.2 \mathrm{~mol} \mathrm{~L}^{-1}$ $\mathrm{NaOH}$ to convert the anilinium, $p$-anisidinium or benzylamonium chlorides salts, that are byproducts of the reaction, into aniline, $p$-anisidine and benzylamine, respectively. The solids were then washed with distilled water and diethyl ether and finally dried under vacuum at $70{ }^{\circ} \mathrm{C}$ for $10 \mathrm{~h}$.

Same procedure was followed to graft 3-phenylpropyl chloride onto the silica gel surface, starting with $\mathrm{SiO}_{2}\left(\mathrm{CH}_{2}\right)_{3} \mathrm{NH}_{2}$.

\section{Infrared analyses}

The cell used in the infrared analyses was especially constructed for this study. The cell has two sections, an oven that consists of an electrical filament on the external wall of the cell and another section where there are two $\mathrm{KBr}$ windows for submitting the sample to the infrared beam using a mobile support. The two sections are pressed together using a viton o-ring. The sample could be heated in the oven area and then moved into the region through which the IR beam passes. Thus the sample is not exposed to the external environment. An illustration of the cell is presented in Figure 1.

Self-supporting disks of materials with an area of $5 \mathrm{~cm}^{2}$ and weighing $50 \mathrm{mg}$ were prepared. The cell described above was connected to a greaseless vacuum line and the system was pumped for $1 \mathrm{~h}$ at a pressure lower than $10^{-2} \mathrm{~Pa}$, at several temperatures. The spectra were obtained at room temperature, after 100 scans, with a resolution of $4 \mathrm{~cm}^{-1}$, in a Bomem model MB-102 FTIR equipment.

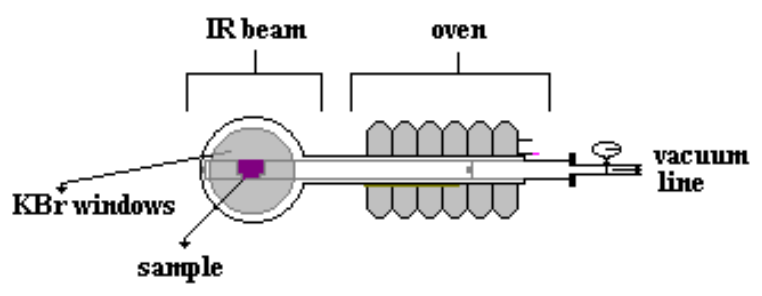

Figure 1. Cell for FTIR analysis.

\section{Elemental Analysis}

The organic groups grafted on the silica gel surface were analyzed using a Perkim Elmer M CHNS/O Analyzer, model 2400 , in triplicate. The quantities of aromatic organic groups grafted on the silica gel surfaces were $0.32,0.31,0.30$ and $0.42 \mathrm{mmol} \mathrm{g}^{-1}$ for $\mathrm{SiO}_{2} /$ aniline, $\mathrm{SiO}_{2} / p$-anisidine, $\mathrm{SiO}_{2} /$ benzylamine and $\mathrm{SiO}_{2}$ /phenylpropyl, respectively.

\section{Results and Discussion}

For grafting aromatic groups onto the silica surface, the use of an intermediate reagent such as 3-chloropropyltrimethoxysilane or 3-aminopropyltrimethoxysilane, as bridging molecules was necessary ${ }^{2,5-8}$. After the intermediate reactions the aromatic groups could be immobilized. Aniline, $p$-anisidine and benzylamine were grafted onto the silica gel surface using as intermediate 3chloropropyl-trimethoxysilane. In the 3-phenylpropyl chloride case, the bridging molecule used was the 3aminopropyl-trimethoxysilane. 
In these reactions $\left(\mathrm{SN}_{2}\right) \mathrm{HCl}$ is produced in the same stoichiometry as the grafted groups. The acid will react with aniline, $p$-anisidine or benzylamine, producing the anilinium, $p$-anisidinium or benzylamonium chloride salts that are byproducts, thus the reaction stoichiometry should be 2:1 (aniline, anisidine or benzylamine: $\mathrm{SiO}_{2}\left(\mathrm{CH}_{2}\right)_{3} \mathrm{Cl}$ ). The resulting solid should be washed with a $\mathrm{NaOH}$ solution to convert the salts to the respective bases for removal. The resulting solids were extensively washed with solvents (toluene, hexane, ethanol, ether and water) to remove the excess reagent.

\section{Infrared analyses}

The spectra of the intermediates are shown in Figure 2. Spectrum $2 \mathrm{a}$ is that of pure silica gel. In the immobilized intermediate 3-chloropropyl spectrum (spectrum 2c) the C-H stretching bands at $c a .2900 \mathrm{~cm}^{-1}$ and the $\mathrm{C}-\mathrm{H}$ bending bands between 1500 and $1400 \mathrm{~cm}^{-}$ ${ }^{1}$ can be observed. In the 3-aminopropyl case (spectrum $2 \mathrm{~b}$ ), bands at 3340 and $1595 \mathrm{~cm}^{-1}$ could also be observed. These bands are assigned to $\mathrm{N}-\mathrm{H}_{2}$ and $\mathrm{N}-\mathrm{C}$ stretching modes, respectively.

The infrared spectra of aromatic groups grafted on the silica gel surfaces are shown in Figures 3-6 and the main bands of the spectra are listed in Table 1. It was observed that aromatic groups grafted onto the silica gel surface can be identified by their characteristic bands, that are distinguishable from those of the linear chain intermediate. A qualitative analysis of the organic groups immobilized on the silica gel surface can be carried out based on the very similar spectra of pure and supported aromatic groups (Table 1).

The thermal stability of these attached groups was measured by the presence of these bands in the spectra, obtained after treatment at several temperatures, in vacuum $\left(10^{-2} \mathrm{~Pa}\right)$ (see Table 2).
Considering the possible heterogeneity in the disk thickness and taking into account the position changes in the infrared beam, the band areas of Table 2 were calculated using the silica overtone band at $1870 \mathrm{~cm}^{-1}$ as a reference band.

The spectra of aniline, $p$-anisidine and benzylamine, bonded to propyl silica, Figures 3,4 and 5, respectively, show a reduction in the band areas of aromatic groups after heating to $400{ }^{\circ} \mathrm{C}$ (see Table 3), while in the 3phenylpropyl, bonded to propyl silica, case (Figure 6) the band area remains almost constant up to $400{ }^{\circ} \mathrm{C}$. This decrease in the infrared band areas is probably due to the partial decomposition of organic aromatic groups that are desorbed, since the heating is performed in vacuum. Therefore the organic aromatic groups grafted on silica gel surface are thermally stable under high vacuum up to at least $300^{\circ} \mathrm{C}$. This is evidence that the entire bonded chain (aliphatic bridge and aromatic groups) is very strongly bonded to the surface in a covalent form.

The infrared spectroscopic thermal analysis used in this work has some advantages when compared to the TGA technique. Thermal treatment of organofunctionalized silica gel produces organic decomposition and water desorption from the dehydroxylation process, i.e. conversion of silanol into siloxane groups ${ }^{16,17}$. The TGA technique shows total mass loss. On the other hand, with the use of the FTIR apparatus, isolated band analysis can be made and it is possible to distinguish between these two thermally related process. In this work, the aromatic ring stretching bands are very distinguishable from the $\mathrm{C}$ $\mathrm{H}$ and $\mathrm{O}-\mathrm{H}$ stretching bands. In the TGA technique this distinction is difficult. Therefore, the FTIR procedure, using the cell described in this work, can be performed under vacuum or also with a controlled atmosphere.

Table 1. Infrared bands of free organic groups and after being attached to the silica gel surface.

\begin{tabular}{lll}
\hline Organic reagents & $\begin{array}{l}\text { main bands of pure } \\
\text { compounds }\left(\mathrm{cm}^{-1}\right)^{20,21}\end{array}$ & $\begin{array}{l}\text { main bands of attached } \\
\text { compounds on silica }\left(\mathrm{cm}^{-1}\right)\end{array}$ \\
\hline 3-Chloropropyltrimethoxysilane ${ }^{1}$ & $1410,1440,2830,2950$ & $1400 \mathrm{w}, 1441 \mathrm{~s}, 2840 \mathrm{~s}, 2962 \mathrm{vs}$ \\
3-Aminopropyltrimethoxysilane ${ }^{1}$ & $1410,1450,1575,1600,2850,2940,3350$ & $\begin{array}{l}1410 \mathrm{vs}, 1450 \mathrm{w}, 1595 \mathrm{vs}, 2860 \mathrm{~s}, 2950 \mathrm{~s}, \\
3360 \mathrm{w}\end{array}$ \\
Aniline & $1505,1600,3050$ & $1505 \mathrm{vs}, 1604 \mathrm{vs}, 2900 \mathrm{~s}, 3070 \mathrm{w}$ \\
$p$-Anisidine & $1460,1510,1620,3025$ & $1469 \mathrm{~s}, 1514 \mathrm{vs}, 1618 \mathrm{w}, 2940 \mathrm{~s}, 3020 \mathrm{vw}$ \\
Benzylamine & $1450,1490,1600,3010,3350$ & $1455 \mathrm{~s}, 1497 \mathrm{~s}, 1600 \mathrm{vw}, 2950 \mathrm{~s}, 3025 \mathrm{w}$, \\
& & $3060 \mathrm{w}$ \\
3-Phenylchloropropyl & $1450,1500,1610,2950,3025$ & $1455 \mathrm{~s}, 1497 \mathrm{~s}, 1600 \mathrm{~s}, 2850 \mathrm{w}, 2950 \mathrm{~s}$, \\
\end{tabular}

\footnotetext{
${ }^{1}$ Intermediates; vw = very weak, $\mathrm{w}=$ weak, $\mathrm{s}=$ strong, vs = very strong
} 


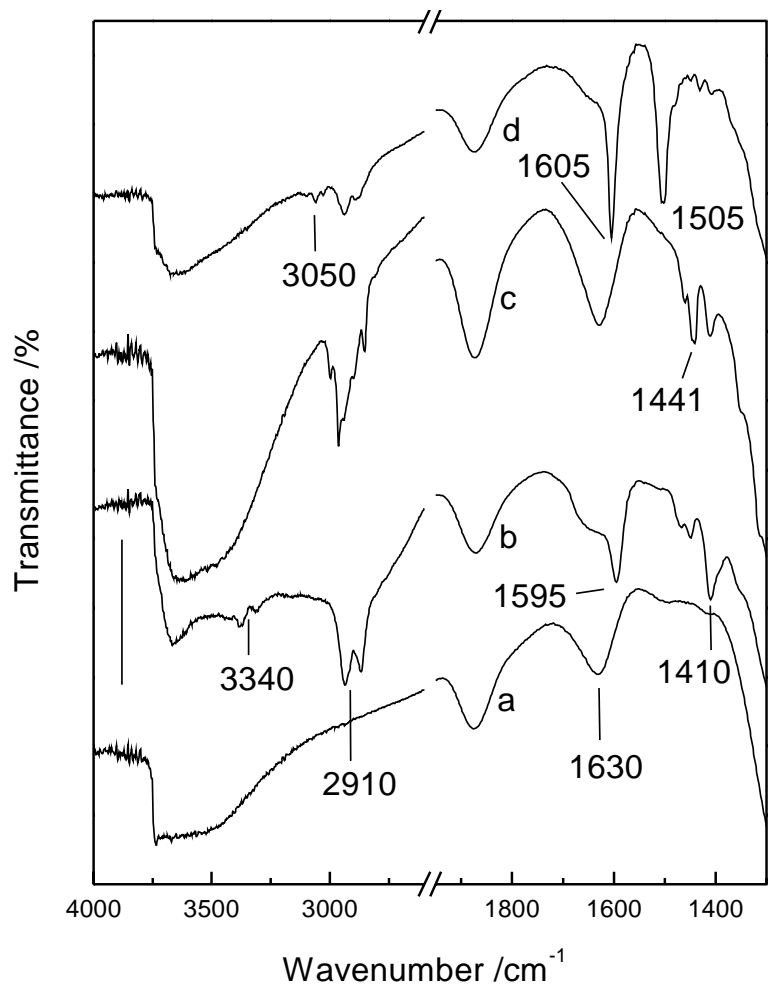

Figure 2. Infrared spectra obtained at room temperature after heating the sample to $200^{\circ} \mathrm{C}$, in vacuum, for $1 \mathrm{~h}$ : a) pure silica gel; b) silica modified with 3-aminopropylsilane; c) silica modified with 3chloropropylsilane. The bar value is $20 \%$.

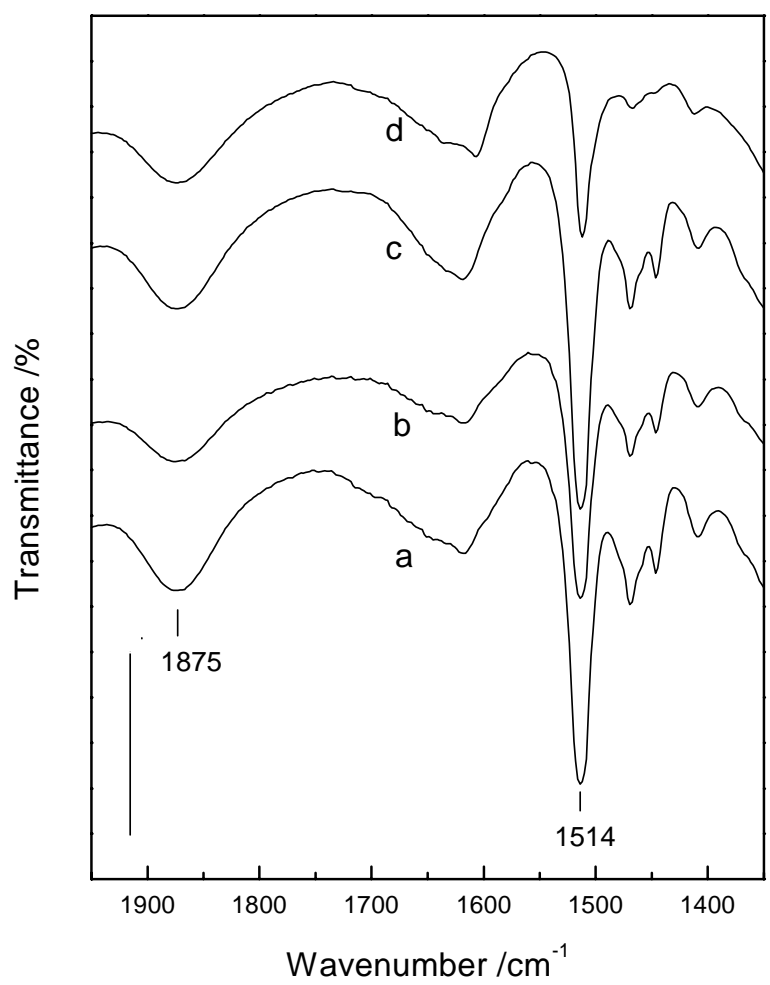

Figure 4. Infrared Spectra of $p$-anisidine grafted to the silica gel surface, obtained at room temperature, after heating in vacuum for $1 \mathrm{~h}$ at: a) $100^{\circ} \mathrm{C}$; b) $200{ }^{\circ} \mathrm{C}$, c) $300^{\circ} \mathrm{C}$, d) $400{ }^{\circ} \mathrm{C}$. The bar value is $20 \%$.

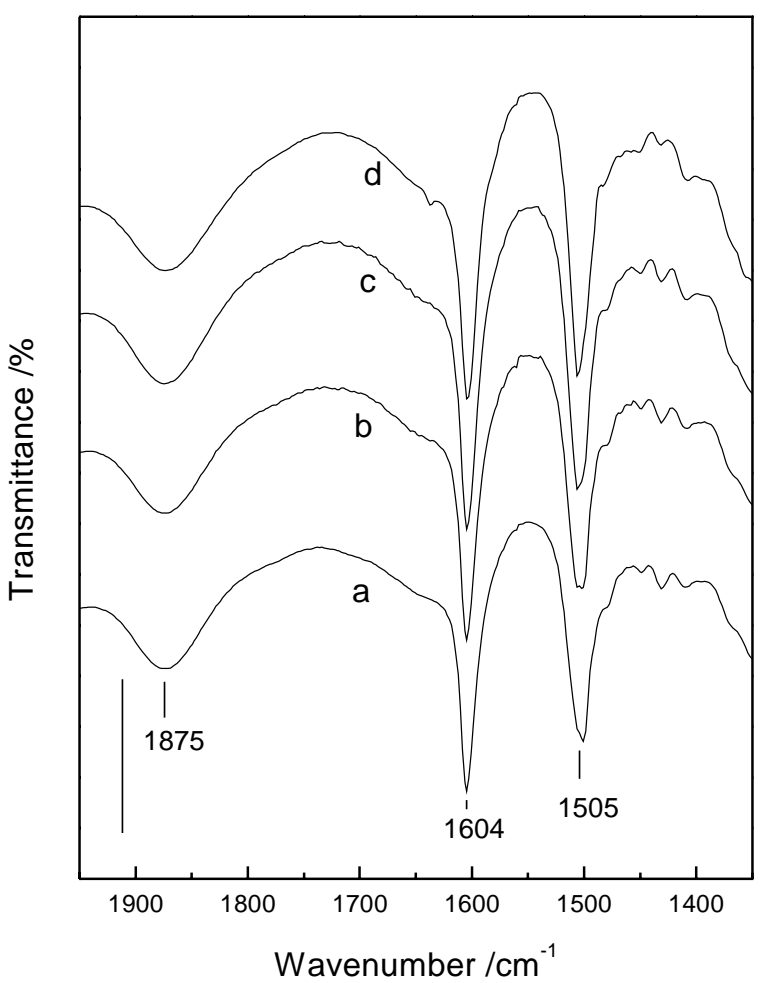

Figure 3. Infrared spectra of aniline grafted to the silica gel surface, obtained at room temperature, after heating in vacuum for $1 \mathrm{~h}$ at: a) $100{ }^{\circ} \mathrm{C}$; b) 200 ${ }^{\circ} \mathrm{C}$, c) $300{ }^{\circ} \mathrm{C}$, d) $400{ }^{\circ} \mathrm{C}$. The bar value is $15 \%$.

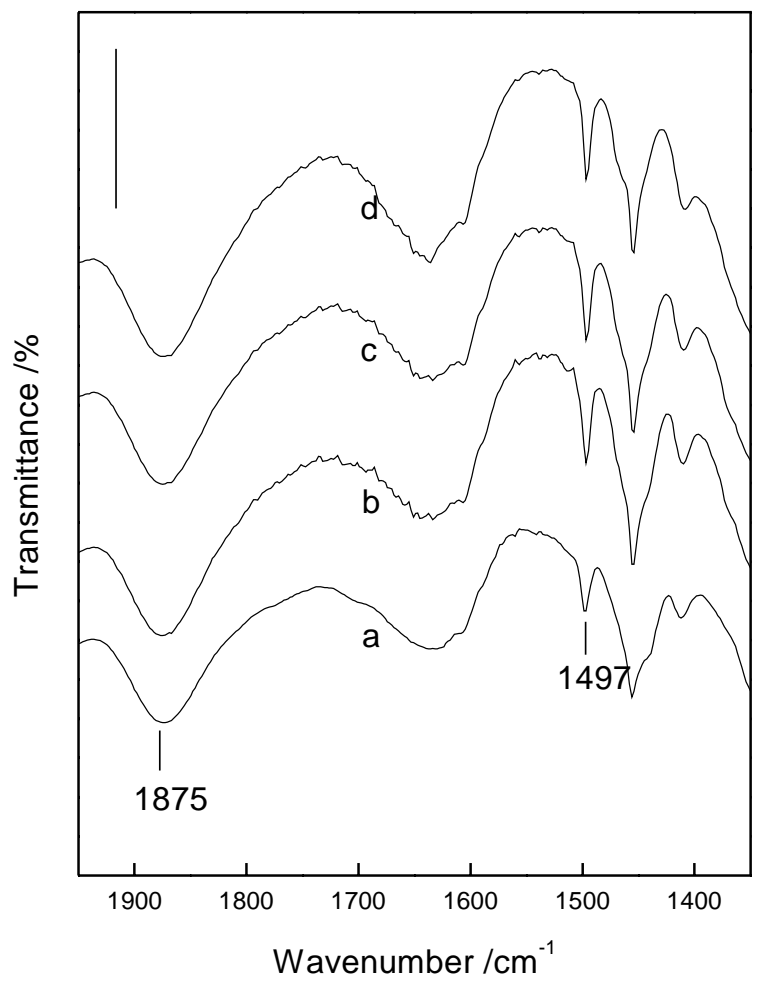

Figure 5. Infrared spectra of benzylamine grafted to the silica gel surface, obtained at room temperature, after heating in vacuum for $1 \mathrm{~h}$ at: a) $100^{\circ} \mathrm{C}$; b) $200{ }^{\circ} \mathrm{C}$, c) $300{ }^{\circ} \mathrm{C}$, d) $400{ }^{\circ} \mathrm{C}$. The bar value is $10 \%$. 


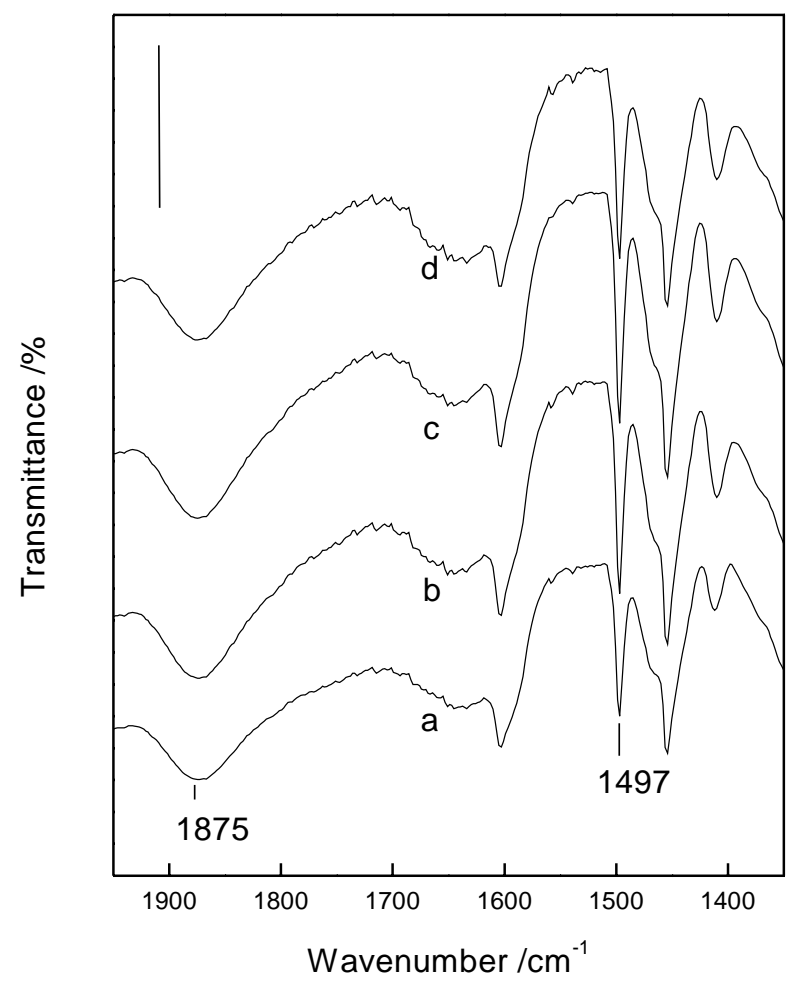

Figure 6. Infrared spectra of 3-phenylpropyl grafted to the silica gel surface, obtained at room temperature, after heating in vacuum for $1 \mathrm{~h}$ at: a) $100^{\circ} \mathrm{C}$; b) $200{ }^{\circ} \mathrm{C}$; c) $300^{\circ} \mathrm{C}$, d) $400{ }^{\circ} \mathrm{C}$. The bar value is $5 \%$.

Table 2. Infrared band areas of aromatic groups grafted on the silica gel surface, heated under vacuum.

\begin{tabular}{lccc}
\hline Material & $\begin{array}{c}\text { temperature } \\
\left({ }^{\circ} \mathrm{C}\right)\end{array}$ & $\begin{array}{c}\text { band } \\
\left(\mathrm{cm}^{-1}\right)\end{array}$ & $\begin{array}{c}\text { band area } \\
\left(\mathrm{cm}^{-1} \mathrm{x} \text { abs }\right)\end{array}$ \\
\hline $\mathrm{SiO}_{2} /$ & 100 & 1505 & 9,44 \\
$\mathrm{Aniline}$ & 200 & & 9,30 \\
& 300 & & 9,74 \\
& 400 & & 7,60 \\
$\mathrm{SiO}_{2} /$ & & & \\
$p$-Anisidine & 100 & 1514 & 22,17 \\
& 200 & & 19,91 \\
& 300 & & 21,80 \\
$\mathrm{SiO}_{2} /$ & 400 & & 5,36 \\
$\mathrm{Benzylamine}$ & & & \\
& 100 & 1497 & 0,65 \\
& 200 & & 0,75 \\
$\mathrm{SiO}_{2} /$ & 300 & & 0,79 \\
$3-$ Phenylpropyl & 400 & & 0,52 \\
& 100 & \multirow{2}{*}{1497} & \\
& 200 & & 2,03 \\
& 300 & & 2,04 \\
& 400 & & 2,10 \\
& & & 2,01 \\
\hline
\end{tabular}

\section{Conclusions}

The aromatic groups, aniline, $p$-anisidine, benzylamine and 3-phenylpropyl can be utilized in grafting reactions with the silica gel surface, using 3-chloropropyl-trimethoxisilane or 3-aminopropyltrimethoxysilane as a bridging molecule. Infrared spectroscopy can be used as a tool for the study of thermal stability of organic groups attached on silica gel surface. This procedure is more versatile than TGA and allows probing a distinct organic group on the surface using the specific infrared band area. The constant values of FTIR band areas of aromatic groups in the spectra obtained up to $300{ }^{\circ} \mathrm{C}$ in high vacuum is evidence of a strong covalent bonded molecule on the silica gel surface.

\section{Acknowledgement}

J. L. F. is indebted to CAPES for a grant.

\section{References}

1. Silberzan, P.; Léger, L.; Ausserré, D.; Benattar, J. J. Langmuir 1991, 7, 1647.

2. Deschler, U.; Kleinschmit, P.; Panster P. Angew. Chem. Int. Ed. Engl. 1986, 25, 236.

3. Moreira, W. C.; Gushikem, Y. Colloids and Surfaces 1987, 25, 155.

4. Belloli, R.; Barletta, B.; Bolzacchini, E.; Meinardi, S.; Orlandi, M.; Rindone, B. J. Chromatog. A 1999, 846, 277.

5. Arakaki, L. N. H.; Airoldi, C. Quím. Nova 1999, 22, 246.

6. Gambero, A.; Kubota, L. T.; Gushikem, Y.; Airoldi, C.; Granjeiro, J. M.; Taga, E. M.; Alcantara, E. F. C. J. Coll. Interf. Sci. 1997, 185, 313.

7. Perruchot, C.; Chehimi, M. M.; Mordenti, D.; Briand, M.; Delamar, M. J. Mater. Chem. 1998, 8, 2185.

8. Jo, H.; Blum, F. D. Langmuir 1999, 15, 2444.

9. Barceló, D.; Hennion, M.-C. Anal. Chim. Acta 1995, 318,1 .

10. Jaroniec, C. P.; Gilpin, A. K.; Jaroniec, M. J. Chromatography A 1998, 797, 103.

11. Jaroniec, C. P.; Kruk, M.; Jaroniec, M.; Sayari, A. J. Phys.Chem.B 1998, 102, 5503.

12. Zhou, Y. W.; Jaroniec, M.; Gilpin, R. K. J. Coll. Interf. Sci. 1997, 185, 39.

13. Soliman, E. M. Anal. Lett. 1998, 31, 299.

14. Adeogun, M. J.; Hay, J. N. Polymer Intern. 1996, $41,123$.

15. Guidotti, B. R.; Herzog, E.; Bangerter, F.; Caseri, W. R.; Suter, U. W. J. Coll. Interf. Sci. 1997, 191, 209.

16. Ying, J. Y.; Benziger, J., B.; Navrotsky, A. J. Am. Ceram. Soc. 1993, 76, 54.

17. Costa, T. M. H.; Gallas, M. R.; Benvenutti, E. V.; Jornada J. A. H. J. Non-Crystalline Solids 1997, 220, 195. 
18. Ai, J.; Phegley, L. L.; Christen, G.; White, R. L J. Am.. Ceram. Soc. 1995, 78, 874.

19. Xiao, C.; Smart, R. B. Appl. Spectrosc. 1991, 45, 1322.
20. Pouchert, C. J. The Aldrich Library of Infrared Spectra, Aldrich Chem. Comp., Edition III, Winsconsin, 1981.

21. Pachler, K. G. R.; Matlok, F.; Gremlich, H.-U. MerckFT-IR Atlas, VCH, Darmstadt, 1988.

Received: November 19, 1999 Published on the web: February 10, 2001 